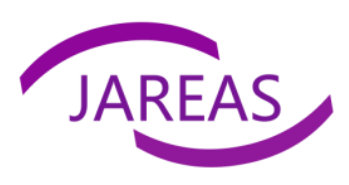

Journal of Advanced Research in Economics and Administrative Sciences

Website: https://bcsdjournals.com/index.php/jareas

ISSN 2708-9320 (Print) and 2709-0965 (Online)

Vol.1, Issue 2, 2020

DOI: https://doi.org/10.47631/jareas.v1i2.85

\title{
Factors Leading to Sustained Growth of SMES in the U.A.E: A Concept Paper
}

\author{
Tirupathi Anand ${ }^{1}$, Arindam Banerjee ${ }^{2}$, Sadia Riaz $^{3}$ \\ ${ }^{1}$ DBA Scholar and Adjunct Faculty, SP Jain School of Global Management, Dubai, United Arab Emirates \\ ${ }^{2}$ Professor, SP Jain School of Global Management, email: Arindam.banerjee@spjain.org \\ ${ }^{3}$ Associate Professor, SP Jain School of Global Management, email:Sadia.riaz@spjain.org
}

\begin{tabular}{|c|c|}
\hline Article Info & Abstract \\
\hline Article histor & Purpose: Small and Medium Enterprises (SME) engaged in the business of \\
\hline Received: 30 September 2020 & Trading and Distribution in the United Arab Emirates are characterized by \\
\hline Revised: 04 November 2020 & fluctuations in the business performance and growth. Even though $95 \%$ of the \\
\hline Accepted: 07 November 20 & $\begin{array}{l}\text { businesses in the UAE are SME sector, the variations in the growth pattern } \\
\text { lead to various challenges which the owner/manager sometimes fails to }\end{array}$ \\
\hline Keywords: & handle well. The aim of this concept paper is to identify the factors \\
\hline Small and medium & contributing to the sustained growth of SME business in the UAE. \\
\hline Enterprises (SME); S & Approach/Methodology/Design: The research problem for this study is "how \\
\hline $\begin{array}{l}\text { Factors; } S \\
\text { United Ar }\end{array}$ & to ensure sustained growth in business for Small and Medium Sized \\
\hline $\begin{array}{l}\text { United Arab Emirates } \\
\text { (UAE); Business }\end{array}$ & Enterprises in the United Arab Emirates". The other studies on SME business \\
\hline Performance & sustaining the performance and growing over a long period of time. This \\
\hline JEL: M10, O12, O16. & $\begin{array}{l}\text { research will specifically focus on the factors contributing to sustained growth } \\
\text { and this will be ascertained through quantitative survey of various SMEs in }\end{array}$ \\
\hline Paper Type : & the UAE. \\
\hline Concept Article & $\begin{array}{l}\text { Findings: This research aims to find the success factors which can be useful } \\
\text { to the SME sector of the UAE in order to achieve sustained growth in } \\
\text { business. As a result of this study, a possible matrix will emerge showing a }\end{array}$ \\
\hline Corre & framework to be applied for sustained growth of business for SMEs. \\
\hline Tirur & $\begin{array}{l}\text { Practical Implications: Sustained growth and longevity of the business } \\
\text { remains the most important dream of every SME owner/manager, and the }\end{array}$ \\
\hline $\begin{array}{l}\text { Email: } \\
\text { tpanand@ @leapexcellence.com }\end{array}$ & $\begin{array}{l}\text { final recommendations of this research will result in a framework which } \\
\text { would help SMEs in the UAE to have a sustained growth in business. } \\
\text { Originality/value: The specific objective of this research is to find "factors }\end{array}$ \\
\hline $\begin{array}{l}\text { ORCID ID: } \\
\text { https://orcid.org/0000-0001- } \\
\text { 6594-7877 }\end{array}$ & $\begin{array}{l}\text { that contribute to the sustained growth in business". This would ensure that, } \\
\text { despite the vagaries in the business environment, the SME owner will continue } \\
\text { to have a stable business with sustained growth over a long period of time. }\end{array}$ \\
\hline
\end{tabular}

\section{Introduction}

The UAE has been the gateway for the entire Middle Eastern Countries and African Countries. The strategic location of UAE in the globe has been very helpful in converting the UAE over the last two to three decades as the hub for the entire Middle East and North Africa region (Middle East Institute, 2013). The country has thrived on this through the Trading and Distribution as well as the Logistics business. The Government of UAE has created a very good world-class infrastructure with good Airport, Sea Ports, Roads and Telecommunication facilities. SME sector is providing employment for $43 \%$ of the total workforce in the country and it contributes $40 \%$ of the total value-add generated by Dubai's economy (Dubai SME, 2015). The trading segment contributes $47 \%$ of the total value-add generated by SME sector (Dubai SME, 2015). Thus, this sector plays a vital role in the economic development of the country (Hamdan, 
2019). In the context of Dubai, SME is the backbone of Dubai's Economy as it contributes 50\% of Dubai's GDP while it accounts for $52 \%$ of the total workforce in the emirate(Arabian Business, 2018). According to the State of Small and medium Enterprises in Dubai, 2019 a report by Dubai SME, an agency of Dubai Economy the SMEs in Dubai represents $99.2 \%$ of the number of establishments in the emirate.

The business scenario of the country is characterized by the vast majority of Small and Medium Sized Enterprises. Most of the SMEs are owner managed and are typically managed in a very traditional style. The company operates as per the intuitive thinking of the Owner-manager. When the economic situation and business sentiments are positive, the owner-manager enjoys the progress and it is tempting to think that the upswing in the economy will continue forever. There is a tendency to think that sky is the limit. This situation has time and again led to overtrading and stretching of the business beyond its tolerable limits. When the economy weakens due to external reasons, the SME, which is not disciplined and has engaged in over-trading, faces severe crisis leading to continued losses and eventual closure of business. Currently, $99.2 \%$ of the establishments in Dubai are classified as SMEs and together, they account for $51 \%$ of the workforce while also contributing around 46\% of the emirate's GDP (SME Report 2019). This significant quotient shows the importance of the SME sector but at the same time exposes the vulnerability of the sector for geo-political and other changes which constantly affects the economy in the UAE.

The inefficient management leading to continued losses has forced SMEs to close down operations abruptly and the UAE has witnessed several instances of expat business owners leaving the country by spreading their losses in the form of unpaid liabilities to creditors and banks (Choudhary, 2019). When sizeable amounts are lost then it does have an impact on the economy and affects the growth of the economy briefly. Empirical results, to a statistically significant extent, conclusively demonstrate that entrepreneurship positively impacts economic growth in the United Arab Emirates (Hamdan, 2019). Family owned businesses have also seen the over-trading, mis-management, diversion of funds, reckless expansion and diversification as some of the brash decisions made by the second generation entrepreneurs have led to severe problems. The family businesses are aware of the transition failure caused by the second generation (Oudah, 2018). There are also several family owned businesses which have seen sustained growth and the factors that have contributed to such companies are conservative approach; risk averse management and strategic decision making (Malik, 2018).

The research gap that has been identified by the researcher is the clear-cut framework for the sustained growth of SME business in the UAE. The objective of this research is to identify and test the factors that lead to sustained growth in business for SMEs through a qualitative and quantitative model in order to arrive at a possible matrix. Thus, this study will focus on the Success Factors that will lead to the sustained growth in business for SMEs in the Trading \& Distribution Business in the UAE. Longevity of the business with sustainable growth over a long period of time can be ensured with Strategic Planning; Innovation; Succession Planning and 
effective Corporate Governance. SMEs need to demonstrate patience for growth and must be highly impatient for profits as propounded by Eliyahu Goldratt.

\section{Literature Review}

The literature review was done by focusing mainly on the last five years of literature in order to ensure the currency and relevance of the body of existing knowledge being reviewed. The Literature Review is divided into three broad parameters, viz., Business Factors, Individual Factors and Sustainable Growth Factors.

\section{Business Factors}

The United Arab Emirates is a federation of seven emirates, viz., Abu Dhabi, Dubai, Sharjah, Ajman, Fujairah, Um Al Quwain and Ras Al Khaimah. There appeared a cultural and management instability which fuelled uncertainty, with a need to accept the benefits of introducing a new more open culture with higher levels of engagement and empowerment being required for substantive change. The European Foundation for Quality Management (EFQM) fundamental concepts of excellence have been studied on Micro, Small and Medium sized enterprises in UAE in the manufacturing sector which led to the overall findings of a weak management systems and a need for enforcement of operational deadlines(Rowland-Jones, 2013). The study is restricted to manufacturing whilst UAE is characterized by a majority of SMEs in Services and Trading\& distribution business sectors.

The backbone of any economy is the Small and Medium Enterprises which play a very crucial and dynamic role in the economic development of a country (Gherghina, 2020).There is no unique, universally accepted and common definition for small and medium enterprises (Berisha, 2015). The quantitative criteria vary from country to country which is based on the economic considerations. There are several qualitative aspects which makes it extremely difficult to draw the line between a Micro, Small and medium enterprise. However, in the context of UAE we have adopted the SME Definition as per "Dubai SME" a division of Dubai Economy Department of Economic Development (DED).An SME is defined as an entity engaged in an economic activity, with a legal form (registered as a business either with a commercial registry like the DED or with a free or industrial zone) and meets the thresholds of employee headcount and turnover as applicable to the industry group it belongs to (Trading / Manufacturing / Services), as specified by the definition.

The classification of the enterprises in the SME category is Micro, Small and Medium which is based on the unique threshold for each business segment as detailed below in Table 1.

Table1: SME Definition as per "Dubai SME" a division of Dubai Economy - Department of Economic Development (DED).

\begin{tabular}{|c|c|c|c|c|c|c|}
\hline \multirow[t]{2}{*}{ Category } & \multicolumn{2}{|c|}{ Trading } & \multicolumn{2}{|c|}{ Manufacturing } & \multicolumn{2}{|c|}{ Services } \\
\hline & $\begin{array}{c}\text { No. of } \\
\text { Employees }\end{array}$ & Turnover & $\begin{array}{c}\text { No. of } \\
\text { Employees }\end{array}$ & Turnover & $\begin{array}{c}\text { No. of } \\
\text { Employees }\end{array}$ & Turnover \\
\hline
\end{tabular}




\begin{tabular}{|c|c|c|c|c|c|c|}
\hline Mico & & & & & & \\
\hline $\begin{array}{c}\text { Enterprises } \\
\text { Small }\end{array}$ & $\leq 5$ & $\leq 3$ Mil & $\leq 9$ & $\leq 3 \mathrm{Mil}$ & $\leq 5$ & $\leq 2$ Mil \\
\hline $\begin{array}{c}\text { Enterprises } \\
\text { Medium }\end{array}$ & $6-50$ & $\leq 50 \mathrm{Mil}$ & $10-100$ & $\leq 50 \mathrm{Mil}$ & $6-50$ & $\leq 20$ Mil \\
\hline Enterprises & $51-200$ & $\leq 250 \mathrm{Mil}$ & $101-250$ & $\leq 250 \mathrm{Mil}$ & $51-200$ & $\leq 200 \mathrm{Mil}$ \\
\hline
\end{tabular}

Source: authors

SMEs have to embrace technology and offer their products and services through Internet as the reach of customers is now moving from local to national to international. Entrepreneur Profile; market; operational management; marketing and promotions; website and digital platform; and products present the highest centrality indices as determinants of SME e-commerce (Barroso, 2019). Retaining customer satisfaction, adopting appropriate infrastructure with lowest possible costs and having adequate awareness and knowledge will help to improve e-commerce. Creating appropriate infrastructure at the lowest possible cost in itself is a big challenge for SMEs which however will bring customer satisfaction. Building the awareness and knowledge of customers is a huge effort which requires dedicated resources of human \& financial capital (Choshin, 2017).

The SMEs go through a rough ride as there are far too many challenges and uncertainties which have to be encountered. There are many challenges to overcome, including financial and marketing conditions before the smooth ride (Mishra, 2018). Market orientation and ability to understand and align with the changes, has a positive effect on business performance compared to technology and alliance orientation within SMEs in Dubai (Al-Ansari, 2015). A structured risk management is very vital for the existence and growth of SMEs (Yap, 2016). Enterprise Risk Management systems are very common among large enterprises but they are largely missing among Small and Medium Enterprises.

Innovation has become the most essential part of the business as technology is involved in every single business and such technology is evolving and changing at a rapid pace over the last 15 years. SMEs must prioritize innovation, change their business models and adapt to a changing environment (Schiliro, 2015). The chances of an innovation-oriented SME succeeding in the export market are far greater than a non-innovation-oriented business (Love, 2015).

Responsible Business Practices and concern for sustainability in order to protect the Environment is hardly one of the top priorities of SMEs. Company's current financial condition is the greatest influence for SMEs to utilize business resources for Responsible Business Practices while ethics only influences to a moderate extent (Cronje, 2017). The social responsibility of the Managers in the SME will play a significant role and has a positive impact on the SME business (Pletnev, 2016). With various issues connected with the environment and with increased level of awareness among people of different parts of the world, it is becoming increasingly important for businesses to be socially responsible in order to grow and ensure 
sustained performance. The sustainable development practices adopted by the SMEs revolves around waste reduction, energy conservation, and improvement to product quality, consolidation of top-line, generation of employment, product safety and safety standards at work (Maheswari, 2018). The business activities of SME in most cases are focused on operational level decisions and there is hardly any focus at the strategic level. Micro, Small and Medium Enterprises in general do not include sustainability in their Mission Statement (Rudawska, 2018). In addition, There is a positive impact on success of SME due to human resources costs; investments in innovation; productivity and venture capital funding. There is a negative impact of firm age and debt (Felix, 2018). The dire need for innovation coupled with the escalating cost of human resources coupled with its scarcity makes the SMEs highly vulnerable.

The importance of financial literacy is well established through various studies in the past. The research study undertaken by Eniola, A. A., \& Entebang, H. in 2016 has helped to focus on the importance of financial literacy for building and aligning Strategic resources; human resources and competitive capabilities which lead to the establishment of competitive advantage. The competitive advantage will help the SME in its performance as there is stiff competition in every industry. There is a significant and positive influence of entrepreneurship, marketing capabilities, relational capital and empowerment towards innovation capability and performance (Sulistyo, 2016). The study is limited to one province and one industry. However, it has created a new knowledge space around Innovation capability and performance of SMEs. Al Ansaari has found that "Market orientation has a positive effect on business performance compared to technology and alliance orientation within SMEs in Dubai". The conclusion that technology orientation is not influencing business performance significantly is questionable as there is enough literature to support that technology orientation does help business performance. The advancement in the technology and its application to various business processes over the last 5 years is proof enough that technology orientation does play a significant role in the business performance.

In fact, the technological advancement and the vast improvement in the digital media have clearly demonstrated that there is a significant influence of Digital Media in the Business Performance particularly in the context of Middle East (Nuseir, 2018). The relationship between Knowledge Management and Business Performance is well established and technology plays a moderating role in motivating the knowledge search (Saqib, 2017). Most strategies pursued by SMEs are short-term in nature, which may be due to their greater focus on emergent strategies. It is true that companies pursuing strategic planning outperform the others as they have a sense of direction and purpose (Siddique, 2015). In the case of family business both environmental and social sustainability practices have a positive relationship. The first generation focuses mainly on financial stability and when the business is passed on to the subsequent generations, the focus shifts towards ensuring the sustainability of the business (Maheswari, 2018).

Entrepreneurship, marketing capability, relational capital and empowerment on innovation are all factors which have a significant impact on the Business Performance (Niazi, 2017). In turn 
the business performance will have a significant positive effect on competitive advantage.

\section{Individual Factors}

A high involvement of non-family members in governance structure has a positive impact on family firms' pace of internationalization. This relationship is mediated by the international entrepreneurial orientation of the firm (Calabro, 2016). Market orientation, entrepreneurial orientation and sustainability practices are related to commitment to sustainability among SMEs (Jansson, 2017). Entrepreneurial Orientation has a positive impact on the implementation of sustainable practices and that social practices at workplace partially mediate the link between Entrepreneurial Orientation and Business Performance (Courrent, 2018).

The ownership and management style of SME also plays a very significant role in aiding the Business Performance and its success. The Success of women-owned SMEs in UAE is significantly affected by Personal, environmental factors and government support (Gupta.N, 2018). The study shows that personal and environmental factors have supported women's decisions in UAE to start and run their business successfully. Some of the earlier studies have also supported this view that the family support and environmental factors had significant effect on the success of women entrepreneurs.

Zaffane, 2015 has argued that "Females are less inclined to become entrepreneurs and are less likely to take risk". Females were also found to be less trusting than males. This study has explored the gender differences in the context of UAE which is an Islamic Country and hence has cultural and religious challenges for Women Entrepreneurs. Personal, environmental factors and government support affect positively and significantly to the success of women-owned SMEs in UAE (Gupta.N, 2018).

Entrepreneurial leadership style does play a very important role in aiding the Business Performance (Sandybayev, 2019). An entrepreneurial strategic orientation enables small businesses to develop a more proactive stance towards environmental sustainability practices which leads to superior firm performances (Roxas, 2017). One of the strategies for SMEs to improve business performance is entry into foreign market. The SME's performance has a positive impact for all the three modes of foreign market entry. However, this positive effect is found to be considerably lower in cooperative modes of market entry as compared to either nonequity modes of market entry or wholly owned subsidiaries (Holtgrave, 2017).

There is a significant relationship between Entrepreneurial Orientation and Business Performance and this relationship can be further nourished with Transformational Leadership as a moderator (Fayaz, 2017). In ensuring Business Performance and growth it is important for the entrepreneur to have International Orientation (Moen, 2016). The export-oriented businesses should have high performance work systems in place in order to enable smooth flow of processes (Hamid, 2017). 
Entrepreneurial orientation is positively associated with Sustainable Development engagement, particularly regarding the environment, human resources, and community involvement (Ayuso, 2018). Small businesses can often respond more quickly to consumer and market changes including environmentally induced changes. The strategic orientation with a proactive approach is the key to adoption of sustainability practices in SMEs leading to firm's performance (Roxas, 2017).

There is a positive and significant relationship between Entrepreneurial Orientation and Firm Performance. Transformational Leadership can be used as a moderator in order to further nourish the relationship between Entrepreneurial Orientation and Firm Performance (Fayaz, 2017).There is a significant positive relationship between entrepreneurial leadership and organisational performance (Sandybayev, 2019). The entrepreneurial leadership qualities are built and nourished through the Entrepreneurial Orientation. Entrepreneurial Orientation will induce willingness-to-change in the minds of the team members and will favour the advancement of a development culture in SME. Entrepreneurial Orientation, willingness-tochange and development culture can lead to new product exploration in SMEs (Dayan, 2016).

There are several factors that contribute to the success of an SMEs and the family support and environmental factors play a significant role (Gupta, 2018). The study found that personal, environmental factors and government support affect positively and significantly to the success of the women-owned SMEs in the UAE. However, the scholars have studied the SMEs owned by women and hence the scope of the study is restricted. The limitation of research done by the scholars is clearly the lower number of women-owned SMEs in the country and many of them being women-owned on paper but not in reality.

\section{Sustainable Growth Factors}

The success of SME and its survival, stability, and sustained growth depends on several factors. Business Support was the most critical factor that significantly affects the success of SMEs in Saudi Arabia, followed by individual factors, capital availability and management factors (AlTit, 2019). The level of adoption of financial literacy by Entrepreneurs of SMEs is low and that the utilization of accounting records does not influence their performance and success rate (Sharma, 2019). The study in the past has established the importance of financial literacy for building and aligning Strategic resources; human resources and competitive capabilities which leads to the establishment of competitive advantage (Eniola, 2016).

Existence of business ideas on one side, and the support programs and resources on the other, are just as good as the linkages between them for the success of start-ups (Poposka, 2016). Most of the SMEs struggle at the start-up phase due to lack of support and scarcity of resources. The business performance of SMEs is strongly influenced by market orientation and the links between technology, alliance orientation and business performance are non-significant within SMEs in Dubai. (Al-Ansaari, 2015). The scholar has tried to link the business performance but has not focused on sustained growth in business. There are also studies focused on Innovation in 
SME and use of social media by SME in the recent times. It is found that higher percentage of manufacturing SMEs are investing into Innovation while the innovation in Trading and Service Sector is very low (Schiliro, 2015).The impact of Digital Media on SMEs performance in the UAE has been found to be lower (Nuseir, 2018).

One of the key factors for Entrepreneurial success in the SME sector is the institutional support which is found to be lacking in the UAE (Sikdar, 2011).There also studies undertaken in the past which were focused on the family owned business and found that the failure of the transition to the second generation is very well known factor (Oudah, 2018).In order to ensure longevity of their business it is important for family owned businesses to give much more importance to succession planning, strategic planning and corporate governance. Saudi Arabia is to an extent a comparable economy as both UAE and Saudi have certain common features. Individual Factors, Business Characteristics, Management Factors, Business Support, Business Environment and Capital Availability have been found to be factors having significant effect on the success of SMEs in Saudi Arabia (Al-Tit, 2019). SME Owners/Managers have to pay close attention to the dominant factors of Success Factors when going through the Organisational Life Cycle stages, with the purpose of achieving maturity and avoiding premature decline (Angeles, 2019).

The Growth trajectory of most of the SMEs is more or less like the roller coaster ride with too many ups and downs. The growth of the SME business is largely dependent on the business environment and external factors. Financial Literacy is key to building strategic relationships and for aligning the strategic resources required for the business (Eniola, 2016). Strategic Resources, Human Resources and Competitive capabilities would help the SME to build the required competitive advantage for achieving sustained growth in business.

The SME business is today not only centred on the local market, but it has also expanded itself into the International Arena. In the present world of business wherein economies have opened up and technology is enabling every facet of business, it is important to stay relevant with the requisite products and services both for the local market as well as for the international market. Innovation and ability to export the products and services to other international markets are two important elements of business for achieving sustained growth in business (Love, 2015).

Large businesses have the requisite infrastructure and resources to back sustained growth in business and that is clearly missing in the case of SMEs. However, the purpose of both the large and SME business is to achieve sustained growth in business and show consistent and improved Business Performance. Wherever possible the SME can adopt the business practices of a large business and ensure sustained growth (Bonsu, 2019). TairuddinYusoff and others in 2018 have introduced the term "sustagrowprises" which denotes sustained growth of SMEs over a long period of time through effective consumption of energy and raw materials while simultaneously achieving employee satisfaction and motivation (Yusoff, 2018). The profitability achieved by the SME should be maintainable and sustainable over a long period of time. As stated earlier the external environment in which the SME operates makes a significant impact on the Business Performance. SME performance is also determined by the external environment, firm's inherent 
characteristics and firm strategy (Ipinnaiye, 2017).It is important for SMEs to set themselves on a path of excellence in order to have sustained growth.

The development of Business Models for SMEs should be focused on sustainability. Business Models incorporating aspects of sustainability do not differ substantially from traditional business models. Business Models undergo constant change, and that sustainability plays a central role, both internally and externally (Rauter, 2017). Framework for Strategic Sustainable Development (FSSD) and Business Model Canvas combination can support business model innovation and design for strategic sustainable development. FSSD bring critical information and guidance for sustainable development but does not provide all the information needed for sustainable development of successful institutions in any given arena (Franca, 2017).The use of FSSD appears to be a recent and underdeveloped approach to embedding sustainability into the BM concepts (Small-Warner, 2018).

The dynamics of doing business in the Middle East needs to be understood in the context of the Islamic Principles. The effects of Strategic Taawun (Co-operation) and fastabiqul Khairat(competing for goodness) in the collaboration partnerships among SMEs in Muslim world are phenomenal for the enterprises to sustain competitive advantage (Sarif, 2019). In the ever-changing environment with stiff competition in every single Industry the survival of the SME is always under threat. The survival probability increases with increasing firm size and firms in different size categories have varying determinants of bankruptcy, whereas factors affecting their financial distress are mostly invariant (Gupta, 2018).Most strategies pursued by SMEs are short-term in nature, which may be due to their greater focus on emergent strategies (Siddique, 2015).

After the initial phase of survival and sustaining the business at a certain level the growth of SME is largely dependent on the ability to reach into the International Markets. Innovation can lead to successful internationalization. Innovation is an important factor that increases the export orientation of SMEs (Kunday, 2015). There is clear evidence of the utility of applying a combination of resource-based and transactional approaches to the conceptualization of international business models. The likelihood of SMEs adopting one business model rather than another is to a high degree predictable with reference to a small set of factors: industry, level of home economy development, and decision-makers international experience (Child, 2017).

The ultimate success of SME is dependent on a variety of factors. There is absolutely no consensus on SME success factors and the existing heterogeneity in knowledge is increasing. Further research is required towards a more unifying theory so as to have a more integrated and comprehensive view of the factors contributing to small business success (Lampadarios, 2017).The present study is an aim towards reaching to the comprehensive view of factors contributing to the sustained growth and success of SMEs, particularly in the context of the UAE. In the competitive world of business, the SMEs must prioritize innovation, change their business models and adapt to a changing environment (Schiliro, 2015). Innovation has become the most essential part of the business as technology is involved in every single business and 
such technology is evolving and changing at a rapid pace over the last 15 years. The UAE is characterized by the existence of a large number of family-owned businesses. Medium sized family business needs to create and give more importance to succession planning; strategic planning and corporate governance to ensure their business longevity (Oudah, 2018).

\section{Methodology and Procedures}

It is a concept paper involving thematic analysis. A detailed analysis of the gaps found in the literature review so far under the above broad six headings, viz., SME; Business Performance; Success Factors; Sustained Growth; UAE and Entrepreneurial Orientation has clearly revealed the need for a "Conceptual Framework" which would help in the identification of some broad factors leading to the sustained growth of SME business in the UAE.

It is realised that a broad theoretical framework needs to be developed to ascertain the Variables. The Business Performance which will be consistent and provide the sustained growth is the Dependent Variable. The Literature Review and detailed analysis of the available body of knowledge suggests that it is better to examine a set of six Independent Variables, viz., Strategic Thinking; Focus on Core Competency; Knowledge Management; Dynamic Business Processes; Sustained Cost Reduction and Financial Discipline.

The critical review of literature has also revealed the importance of two more dimensions which are very crucial for SME sector, viz., Entrepreneurial Orientation and Technology Orientation. These two dimensions will be examined as Moderating Variables in order to test their significance and relevance in light of the independent variables already identified.

\section{Results and Discussion}

\subsection{Critical Analysis of Review of Literature}

SMEs are the backbone of every economy as they have a significant contribution to GDP and a great avenue for Human Resources Development in the country. In the UAE, the role of SME is far more pronounced as they contribute to nearly $90 \%$ of the businesses and hence, they are much more than a backbone of the economy. Specific studies and accretion to the body of knowledge relating to SMEs is of great relevance particularly in the UAE in view of its significant and substantial presence and contribution to the economy.

It can be clearly seen from the available literature that there is no clarity when it comes to factors contributing to sustained growth in business for SMEs in the UAE. Sporadic studies have been conducted on different dimensions of the SME Sector success in the UAE, but there is no concrete evidence leading to a formula for definite success for the SME business in the UAE.

This present study will fill that gap and throw some light on the factors leading to sustained growth of SME business in the UAE. The present study is probably the first attempt in this direction. 


\subsection{Research Gaps}

The existing body of knowledge on Small and Medium Enterprises is much dispersed and covers several issues relating to resources, survival, constraints, sustainability, etc. However, there is no study so far which is entirely focused on the SME in the UAE with specific reference to its performance and sustained growth.

The available literature is very helpful to see the relationship between Business Performance and various enablers like Entrepreneurial Orientation, International Orientation, Strategy Orientation, Foreign market entry, Exports, Leadership Styles, etc. However, there are various other aspects which are both qualitative and quantitative which have a significant relationship with the Business Performance. Particularly in the context of the UAE which is dependent on the external environment to a large extent, being a predominantly re-export-oriented place.

The available literature is scattered around various factors that could lead to sustained growth in business for SMEs and is not clear in terms of the factors contributing to the sustained growth of business in the UAE. The UAE market is unique and is acting as the gateway for the whole of Middle East and Africa. The SME business in the UAE is largely dependent on the geo-political and economic developments in the Middle East, Africa and to large extent Eastern Europe.

\section{Conclusion and Suggestion}

The conceptual understanding so far needs to be further tested for a comprehensive study which will be conducted by adopting both qualitative and quantitative methods in combination. The study will begin with in-depth analysis of a few Small and Medium Sized Enterprises in the Trading \& Distribution Business. The qualitative analysis of the few companies will lead us to the success factors that are contributing to the success of the companies and at the same time it would reveal the challenges that are faced by these SMEs in achieving sustained growth.

Based on the findings of the qualitative analysis of SMEs, an instrument will be developed to cover various aspects that help in the growth of business. This instrument will be in the form of a detailed questionnaire and it will be administered on a sample of 50 to 100 SMEs that are in Trading and Distribution Business in the UAE. The response from the sample of SMEs will then be tabulated and analysed using the most appropriate statistical tools. This quantitative analysis will then help us to come up with a probable "Sustainable Framework" for achieving sustained growth in business for SMEs in UAE. The Sustainable Framework that will emerge at the end of the detailed research study will be a landmark contribution to the SME sector in the UAE as the economy is driven by the large presence of SMEs.

\section{Conflict of interests}

The authors declare no conflict of interest. 


\section{Funding}

The study has no financial assistance/ funds to recognise.

\section{References}

Al-Ansaari, Y., Bederr, H., \& Chen, C. (2015). Strategic orientation and business performance. Management Decision.

Al-Tit, A., Omri, A., \& Euchi, J. (2019). Critical success factors of small and medium-sized enterprises in Saudi Arabia: Insights from sustainability perspective. Administrative Sciences, 9(2), 32.

Angeles, A., Centeno, E. and Villanueva, C.E., (2019). Examining Structural Flexibility Factors in SMEs: A Mixed Methods Study in Mexico. Electronic Journal of Business Research Methods, 17(1).

Ayuso, S. and Navarrete-Báez, F.E., (2018). How does entrepreneurial and international orientation influence SMEs' commitment to sustainable development? Empirical evidence from Spain and Mexico. Corporate Social Responsibility and Environmental Management, 25(1), pp.80-94.

Barroso, R.M., Ferreira, F.A., Meidutė-Kavaliauskienè, I., Banaitienė, N., Falcão, P.F. and Rosa, Á.A., (2019). Analyzing the determinants of e-commerce in small and medium-sized enterprises: a cognition-driven framework. Technological and Economic Development of Economy, 25(3), pp.496-518.

Berisha, G. and Pula, J.S., (2015). Defining Small and Medium Enterprises: a critical review. Academic Journal of Business, Administration, Law and Social Sciences, 1(1), pp.17-28.

Bonsu, S. and Kuofie, M., (2019). Small Business Survival. Journal of Marketing \& Management, 10(1).

Calabrò, A., Campopiano, G., Basco, R. and Pukall, T., (2017). Governance structure and internationalization of family-controlled firms: The mediating role of international entrepreneurial orientation. European Management Journal, 35(2), pp.238-248.

Child, J., Hsieh, L., Elbanna, S., Karmowska, J., Marinova, S., Puthusserry, P., Tsai, T., Narooz, R. and Zhang, Y., (2017). SME international business models: The role of context and experience. Journal of World Business, 52(5), pp.664-679.

Choshin, M. and Ghaffari, A., (2017). An investigation of the impact of effective factors on the success of e-commerce in small-and medium-sized companies. Computers in Human Behavior, 66, pp.67-74.

Courrent, J.M., Chassé, S. and Omri, W., (2018). Do entrepreneurial SMEs perform better because they are more responsible?. Journal of Business Ethics, 153(2), pp.317-336.

Cronje, L., Ferreira, E.J. and van Antwerpen, S., (2017). Responsible business practices: Aspects influencing decision-making in small, medium and micro-sized enterprises. African Journal of Business Ethics, 11(1).

Dayan, M., Zacca, R., Husain, Z., Di Benedetto, A. and Ryan, J.C., (2016). The effect of entrepreneurial orientation, willingness to change, and development culture on new product exploration in small enterprises. Journal of Business \& Industrial Marketing. 
Eniola, A.A. and Entebang, H., (2016). Financial literacy and SME firm performance. International Journal of Research Studies in Management, 5(1), pp.31-43.

Fayaz, M. and Shah, S.A., (2017). Relationship between Entrepreneurial Orientation and Firm Performance: Moderation of Transformational Leadership in the Context of Pakistani SMEs.

Félix, E.G.S. and dos Santos, J.A.K., (2018). The success factors for SMEs: Empirical evidence. Journal of Applied Economics \& Business Research, 8(4).

França, C.L., Broman, G., Robert, K.H., Basile, G. and Trygg, L., (2017). An approach to business model innovation and design for strategic sustainable development. Journal of Cleaner Production, 140, pp.155-166.

Gherghina, Ș. C., Botezatu, M. A., Hosszu, A., \&Simionescu, L. N. (2020). Small and MediumSized Enterprises (SMEs): The Engine of Economic Growth through Investments and Innovation. Sustainability, 12(1), 347.

Gupta, J., Barzotto, M. and Khorasgani, A., (2018). Does size matter in predicting SMEs failure?. International Journal of Finance \& Economics, 23(4), pp.571-605.

Gupta, N. and Mirchandani, A., (2018). Investigating entrepreneurial success factors of womenowned SMEs in UAE. Management Decision.

Hamdan, A.M.M., (2019). Entrepreneurship and Economic Growth: An Emirati Perspective. The Journal of Developing Areas, 53(1).

Hamid, Z., (2017). Impact of high-performance work systems on export-oriented SMEs performance: the mediating role of human capital development. The South East Asian Journal of Management.

Holtgrave, M. and Onay, M., (2017). Success through trust, control, and learning? Contrasting the drivers of SME performance between different modes of foreign market entry. Administrative Sciences, 7(2), p.9.

Ipinnaiye, O., Dineen, D. and Lenihan, H., (2017). Drivers of SME performance: a holistic and multivariate approach. Small Business Economics, 48(4), pp.883-911.

Jansson, J., Nilsson, J., Modig, F. and HedVall, G., (2017). Commitment to sustainability in small and medium-sized enterprises: The influence of strategic orientations and management values. Business Strategy and the Environment, 26(1), pp.69-83.

Kunday, Ö. and Şengüler, E.P., (2015). A study on factors affecting the internationalization process of small and medium enterprises (SMEs). Procedia-Social and Behavioral Sciences, 195, pp.972-981.

Lampadarios, E., Kyriakidou, N. and Smith, G., (2017). Towards a new framework for SMEs success: a literature review. International Journal of Business and Globalisation, 18(2), pp.194-232.

Love, J.H. and Roper, S., (2015). SME innovation, exporting and growth: A review of existing evidence. International small business journal, 33(1), pp.28-48.

Maheswari, B.U., Kavitha, D. and Nandagopal, R., (2018). Sustainability practices and firm performance in small and medium sized family run firms: A generational perspective. Journal of Management Research, 18(2), pp.127-136.

Maheswari, B.U., Nandagopal, R. and Kavitha, D., (2018). Sustainable Development Practices 
Adopted by SMEs in a Developing Economy: An Empirical Study. IUP Journal of Management Research, 17(3).

Malik, A.L.S., (2018). An Evaluation of the Organizational Performance of Family Firms in the Gulf Region: Factors Impacting Sustainable Business Growth (Doctoral dissertation, Cardiff Metropolitan University).

Mishra, R., Mishra, G.P., Mishra, K.L. and Hatmi, B., (2018). Understanding the Paradoxical Drop in Growth of Small and Medium Entrepreneurs-Cause, Challenges and Concerns. International Journal of Entrepreneurship, 22(2), pp.1-17.

Moen, Ø., Heggeseth, A.G. and Lome, O., (2016). The positive effect of motivation and international orientation on SME growth. Journal of Small Business Management, 54(2), pp.659-678.

Muhammad Siddique, C., (2015). A comparative study of strategic planning practices of SMEs and large-sized business organizations in emerging economies: The case of UAE. Strategic Change, 24(6), pp.553-567.

Niazi, A., (2017). The Role of Entrepreneurship, Innovation and Marketing Capability in Small and Medium-Sized Enterprises (SMEs). International Journal of Economic Perspectives, 11(3).

Nuseir, M.T., (2018). Digital media impact on SMEs performance in the UAE. Academy of Entrepreneurship Journal, 24(2), pp.1-13.

Oudah, M., Jabeen, F. and Dixon, C., (2018). Determinants linked to family business sustainability in the UAE: An AHP approach. Sustainability, 10(1), p.246.

Pfeffer, J. and Salancik, G.R., (2003). The external control of organizations: A resource dependence perspective. Stanford University Press.

Pletnev, D. and Barkhatov, V., (2016). Business success of small and medium sized enterprises in Russia and social responsibility of managers. Procedia-Social and Behavioral Sciences, 221, pp.185-193.

Poposka, K., Nanevski, B. and Mihajlovska, E., (2016). The start-up phase in SME development: Main challenges, motives, and financing opportunities. Journal of Sustainable Development, 6(16), pp.45-60.

Rauter, R., Jonker, J. and Baumgartner, R.J., (2017). Going one's own way: drivers in developing business models for sustainability. Journal of Cleaner Production, 140, pp.144-154.

Rowland-Jones, R., (2013). A perspective on United Arab Emirates small and medium-sized enterprises management utilising the European Foundation for Quality Management concepts of excellence. Total Quality Management \& Business Excellence, 24(1-2), pp.210-224.

Roxas, B., Ashill, N. and Chadee, D., (2017). Effects of entrepreneurial and environmental sustainability orientations on firm performance: A study of small businesses in the Philippines. Journal of Small Business Management, 55(sup1), pp.163-178.

Rudawska, E., \&ZhannaBelyaeva, Z. (2018). The Influence Of Changes In The Contemporary Business Environment On Companies'mission And Goals-The Example Of Selected European Countries. International Journal of Sales, Retailing \& Marketing, 7(2).

Sandybayev, D., (2019). Impact of Effective Entreprenerial Leadership Style on Organizational 
Performance: Critical Review. Bagheri, A.(2017). The impact of entrepreneurial leadership on innovation work behavior and opportunity recognition in high-tech, pp.4755.

Saqib, M., Baluch, N.H. and Udin, Z.M., (2017). Moderating Role of Technology Orientation on the Relationship between Knowledge Management and SMEs' Performance in Oman: A Conceptual Study. International Journal of Economic Perspectives, 11(1).

Sarif, S.M., (2019). Strategic Ta'awun And Fastabiqul Khairat Partnerships For Sustainable Competitive Advantage Among Small And Medium Enterprises In The Muslim World. Asian Academy Of Management Journal, 24.

Schilirò, D., (2015). Innovation in small and medium enterprises in the United Arab Emirates. Int'l J. Soc. Sci. Stud., 3, p.148

Sharma, A., (2019). The Influence of Financial Literacy on the Performance of Small and Medium-Scale Enterprises. IUP Journal of Accounting Research \& Audit Practices, 18(2), pp.52-61.

Sikdar, A. and Vel, K.P., (2011). Factors influencing entrepreneurial value creation in the UAEAn exploratory study. International journal of business and social science, 2(6), p.77

Small-Warner, K., Abuzeinab, A. and Taki, A., (2018). A review of sustainable business models and strategic sustainable development. Journal of Business Models, 6(2), pp.84-89.

Sulistyo, H., (2016). Innovation capability of SMEs through entrepreneurship, marketing capability, relational capital and empowerment. Asia Pacific Management Review, 21(4), pp.196-203.

Yap, K.H.A. and Yap, S.T., (2016). Enterprise risk management: evidence from small-medium enterprises/Yap KiewHeong Angeline and Yap Saw Teng. Management \& Accounting Review (MAR), 15(2), pp.1-20.

Yusoff, T., Wahab, S.A., Latiff, A.S., Osman, S.I., Zawawi, N.F. and Fazal, S.A., (2018). Sustainable Growth in SMEs: A Review from the Malaysian Perspective. J. Mgmt. \& Sustainability, $8, \mathrm{p} .43$.

Zeffane, R., (2015). Trust, personality, risk taking and entrepreneurship. World Journal of Entrepreneurship, Management and Sustainable Development. 